\title{
Strengthening Law and Protection System of Geographical Indications in Maintaining the Value of a Local Product in the Globalization Era
}

\author{
Ilham Potimbang \\ \{Ilham_potimbang1@student.uns.ac.id\} \\ Department of Law, Universitas Sebelas Maret, Indonesia
}

\begin{abstract}
Geographical indication products have advantages both in terms of quality, value, and characteristics of a product indicating the origin of an item that has been recognized by the Regulation through a registration mechanism. Utilization Protection geographical indications give the value of an item to be relatively high to be marketed. This has an impact on the marketing and counterfeiting systems of products marketed on the local and international markets without having to follow the procedures and mechanisms in the Geographical Indication protection requirements book. This study aims to strengthen the value of Geographical Indications products of counterfeiting and marketing mechanisms in maintaining the quality and value and quality of an item by using empirical Normative legal research methods. The discussion that in the current free-market era, the concept of agreement in TRIPs has given authority to the State to protect local products with the potential for geographical indications with intellectual property protection. In the field, there are still many similar local products that have the same name as local product names. Geographical Indications, but have different qualities, tastes, and characteristics. These marketing practices allow forgeries to have an impact on the level of value of a product.
\end{abstract}

Keywords: Legal Reinforcement, Marketing Systems, Geographic Indication Products.

\section{Introduction}

In the era of free trade, Geographical Indication Products receive special attention and treatment in The Related Aspects of Intellectual Property Rights, specifically an agreement to protect all kinds of products both raw products and products produced through a system of geographical indication protection or origin of goods.

The protection of geographical indications is regulated in several international agreements or conventions, including the Paris Convention, the Madrid Agreement, the Lisbon Agreement, and the TRIPs Agreement. The Agreement or Convention has similarities and differences with each other for example in the use of the term geographical indication but has a role in the development of the protection of geographical indications. International agreements or Conventions on geographical indications are useful both in terms of consumers and producers of a commodity product. This agreement avoids producers from being disadvantaged from artificial product commodities which of course have different characteristics and qualities to create a different reputation from the original product. While in terms of consumers can get authentic products with quality tested and 
guaranteed. In Indonesia, protection of geographical indications contained in Law Number 20 the Year 2016 Regarding Geographical Marks and Indications and Government Regulation Number 51 the Year 2007 Regarding Geographical Indications.

In this study, there are three important elements in the protection of geographical indications [1] viz:

1.1 Legal Protection System

Counterfeiting is the basis for the legal protection of a geographical indication product so that the authenticity of a product can be guaranteed its authenticity. The TRIPs Agreement provides an opportunity for a country to provide legal guarantees and protection for products that give the country of origin the characteristic.

1.2 Characteristics of a Product

The characteristics that are maintained in a product both raw and processed products that have distinguishing features characterize the quality of similar products both in terms of geographical and human behavior giving special characteristics. Protection of geographical indications must be able to maintain a reputation both in terms of geography and the level of processing to keep the order of the product from extinction resulting in loss of protection of geographical indications.

1.3 Quality

Quality assurance of a product's geographical indications affects the economic value of a product. With the protection of geographical indications, it is expected that product quality can be maintained both from the empowerment system and its processing.[2]

Some countries, especially France, which are already known as producers of wines and spirits, and several other countries such as India as the country of origin of the "Basmati" rice variety, proposed a new concept of special protection for quality goods and have character or characteristics. Typical that is only found in the country, so the product outside the country has a very high economic value. However, the emergence of free trade and open business competition with a high technology system now has positive and negative impacts on the trade of a geographical indication product. With the legal protection of product geographical indications provide high value to the product marketing system.[3] The main reason for providing a geographical indication protection system is because in reality, both wine products from France and rice from Basmati varieties originating from India, are also grown and mass-produced in several other countries by using indications (signs) as if originating from his home country. For France, the act of producing a product that seems to originate from its place of origin is one mode of cheating categorized as unfair business competition (Unfair contest). Actions by other producers outside their home country are considered by France as a trade practice that is contrary to the Fairtrade principles. [4]

The Protection of geographical indications in Indonesia is considered not optimal because the majority of geographical indication products are agricultural and plantation products so that the use of geographical indication brands and Plant Varieties is difficult to distinguish among consumers.[5] Many entrepreneurs still market products by the refinement of geographical indication products because they see the type of registered varieties that are the same as the geographical indication products. We still find many local products such as the types of salak pondoh and sweet potato Cilembu but have different qualities and characteristics from the original protected products with the protection of 
geographical indications that can affect the type of quality and value of a geographical indication product. Also, the case of Kopi Toraja registered in Japan as a trademark of Toarco Toraja No. Registration 75884722; as well as the Gayo Montain Coffee trademark claim against Gayo Coffee with CTM Registration. 001242965 by a Dutch company, at a time when there will be a repeat of other Indonesian original products. [6]

In the example case above, consumers in other countries may not know that the product consumed is not authentic (geographical indication) from their home country. Likewise, what is considered to be no less important is that the act of producing goods as if they were originally from their original place has economically disadvantaged the company or the community that produces the product from which the product originated. From the substance aspect, the issue of product protection through the registration system of geographical indications is not only related to the concept of protection of Intellectual Property especially the protection of [7] Trademarks that refer to the TRIPs Agreement, but it also has to do with the concept of [8] protection of Germplasm (Biodiversity) as a genetic source and protection of Traditional Knowledge The community (The farmer indicates geography and traditional knowledge) as stipulated in the Rio Conventions, Cartagena Conventions and UPOV Conventions for Plant Varieties. The problem is how the geographical indication protection law can maintain and maintain the characteristics and quality of a geographical indication product from counterfeiting not only in the registration procedure but can guarantee authenticity to the level of entrepreneurs and consumers both locally and internationally to maintain and increase the economic value of a geographical indication product in increasing economic value and maintaining the original reputation of a product. The purpose of this study as a reference for the strengthening and legal protection system of Geographical Indications products as a basis for strengthening the economy of the local community in the area of origin of the geographical indication.

\section{Research Method}

The research method used is a descriptive qualitative research method, which is by trying to give an idea of the actual problem today based on the facts that appear. This research method opens up opportunities for a juridical analysis approach in finding justice in the protection of geographical indications.

2.1 Nature of Research

This research is normative juridical with the type of legal research that takes library data. In this research, library materials are basic research data classified as secondary data.

2.2 Data Types

This research is normative juridical, therefore using secondary data consisting of:

2.2.1 Primary data, This primary data includes laws governing intellectual property, specifically regarding geographical indications.

2.2.2 Secondary data, namely library materials that contain information about primary legal materials, consisting of literature on intellectual property, especially geographical indications, seminar materials,[9] newspapers and magazines, symposiums, and so on. 
2.2.3 Tertiary data, that is supporting legal materials that guide primary and secondary legal materials between other forms of a legal dictionary.

2.3 Data Analysis Techniques Data analysis techniques are used with a qualitative approach. In a qualitative approach, no statistical parameters are used.

\section{Discussion}

3.1 Legal Protection of Geographical Indications [10]

Based on the theory of legal protection can be done in 2 (ways) namely preventive legal protection and repressive legal protection. Relating to legal protection through geographical indications as part of intellectual property has received international attention,[11] so various international treaties regulate it. International legal protection of geographical indications can be found in the Paris Convention for the Protection of Industrial Property in 1983 and the Madrid Agreement in 1891.[12] Both Agreements mention "Indication of Source as an indication referring to a country or a place in that country, as being the country or place of a geographical indication of a product.[13] " The origin indication is a sign that points to a country or a place in a particular country, where the goods were produced. Article 22 of the Geographical indications are for the purposes of this agreement, indications which indentify a good as orindikasi geografisinating in the territory of a member, or a region or locality in that territory, where a given quality, reputation or other characteristics of the good is essentially attributable to its geographical orindikasi geografisin. TRIPs defines geographical indications as a sign that identifies a territory of a member country, or region, or region within the territory as the origin of the goods, where the reputation, quality, and characteristics of the goods concerned are largely determined by geographical factors. Thus, the origin of a particular item that is attached to the reputation, characteristics, and quality of an item that is associated with a particular area is protected legally.

Trade-Related Aspects of Intellectual Property Geographical references including Trade in Counterfeit Goods / TRIPs [14] aim to:

3.1.1 Increase protection of Intellectual Property of traded products;

3.1.2 Guarantee the procedures for implementing Intellectual Property that does not hamper trading activities;

3.1.3 Formulating rules and disciplines regarding the implementation of protection of Intellectual Property;

3.1.4 Develop principles, rules, and mechanisms of international cooperation to deal with the trade in counterfeit goods or piracy of Intellectual Property.

Preventive protection arrangements at the national legal level relating to geographical indications are definitively regulated in the Trademark Law and Geographical Indications and Government Regulations on Geographical Indications. In Chapter VIII Article 53 paragraph (1) of the [15] Trademark Law and Geographical Indications[16] explicitly stated that the protection of geographical indications is given after the registration of geographical indications.[17] This means that the protection of the right to geographical indications[18] must be done through registration with the Directorate General of Intellectual Property.[19] Further, it is regulated in paragraph (3) that the Applicant who will register the protection of Geographical Indications is: 1) an institution representing the community in a certain geographical area that is commercializing an item and/or product in the form of (a) 
natural resources, (b) handicraft goods hand, or (c) industrial products; 2) provincial or district/city government.[20]

According to Satjipto Raharjo, legal protection is to protect human rights that have been harmed by others and that protection is given to the public so that they can enjoy all the rights granted by law.[21] The law can function to realize protection that is not merely adaptive and flexible, but also predictive and anticipatory. Law is needed for those who are weak and not yet strong socially, economically, and politically to obtain social justice.[22]

3.2 Strengthening Characteristics, Quality, and Value of a Local Product Geographical Indications

The protection of geographical indications as part of intellectual property is inseparable from the consideration of the economic value inherent in a product. This is because the use of labels or marks Geographical indication embodies the quality of products or goods produced by a particular region or region. This is what will indirectly add economic value to the products or goods produced by the country or region. Moreover, Indonesia is rich in traditional knowledge, traditions, and culture. Indications must have distinctive characteristics that are indeed a distinguishing power/characteristic of products produced from other regions. Because it is indeed a geographical indication as one of the signs that indicate the origin of the product, its characteristics, and its reputation.

Characteristics of products that have been registered in the protection of geographical indications in general, several added values affect the competitiveness of the products concerned when entering the market, as follows:

3.2.1 International recognition of geographical indications as part of intellectual property means that the status of the holder of geographical indications is that of exclusive rights holders protected by law as is the case with other Intellectual Property objects;

3.2.2 The Geographical Indication is not given to a particular individual, but rather is given to a group of people so that the holder of this geographical indication right is shared or communal;

3.2.3 Unlike the protection of trademarks that are individualistic so that the economic benefits of the trademark are only enjoyed by the trademark owner, the concept of ownership in geographical indications is communal ownership, so that the economic benefits are automatically enjoyed by the community concerned which is much wider if compared to brands that are only owned individually;

3.2.4 Within a trademark, parties to geographical indications who wish to enjoy the economic benefits of a registered trademark can obtain through a business contract mechanism such as a licensing contract. Whereas ownership of geographical indications cannot be licensed so that economic benefits are only enjoyed by the community groups concerned;

3.2.5 Since economic rights are only owned by the holder of geographical indications, then from the trading strategy, of course, the community group will always maintain aspects of the quality (reputation) of the products it produces, so that maintaining the substantive conditions given the relevant geographical indications are consistently maintained, once geographical indications maintain consumer loyalty; 
3.2.6 In terms of product marketing (marketing), with the limited holders of geographical indications, then automatically, they do not have competitors so they can sell their products above the prices of other similar products. Meanwhile, from the consumers themselves, of course, they do not mind paying more, because they realize that the quality of their products is certain to meet the standards;

3.2.7 In the area of production, centers can be used as a model of the tourism industry.

The urgency of this legal protection is also very important, given that Indonesia is a member of the WTO, which has ratified the GATT (including TRIPs). Ideally, it has been prepared in such a way that it is not just a legal instrument oriented to legal protection of intellectual property which has implications for the interests of the community. Further implications will certainly be very helpful in creating a country profile that truly protects local products.

The TRIPs Agreement also contains elements that need to be considered in terms of national laws and regulations regarding Intellectual Property, namely: a. Make new norms; b. Have a higher standard; c. Contains law enforcement provisions that obey.

The signing of the TRIPs agreement for Indonesia in particular geographical indications has a high enough value because the ownership character of collective or communalistic geographical indications is in line with the cultural values of Indonesian people who value mutual ownership rather than private ownership. The existence of this characteristic of communal ownership shows the principles of intellectual property ownership in geographical indications namely the territorial principle, collective principle, communal principle, agreement principle, and mutual benefit, the principle of justice. Geographical indications have the potential to be developed to protect the products of indigenous peoples and local communities which are generally named not after individual names, but where the origin of a product will be protected by geographical indications.

At present, Indonesia is a country rich in potential geographical indication products such as Cilembu Sweet Potato, Gayo Coffee, Bali Kintamani Coffee, Lampung Black Pepper, Muntok White Pepper, Toraja Coffee, Malang Stone Apples, Malang Dinoyo Ceramics, Kasongan Pottery, and others. The natural potential is a gift for the Indonesian people for economic growth if the potential can be exploited and indicated as a trade asset. In this context, if the potential is included in the category of business or trade assets, the rule of law must be able to guarantee that the rights of those who exploit this potential can be protected. Especially if the potential has been traded internationally (export and import). This encourages protection not only in substance but acts of protection both from right holders and falsification of geographical indication products.

Some reasons for the lack of maximum legal protection for the protection of geographical indication products include the indication of the still weak legal protection of local products, as a condition of substance and enforcement and carrying out the protection of geographical indication products. With the change in protection, especially in Indonesia with Law No. 20 of 2016 concerning Brands and Geographical Indications, is adequately regulated from protection requirements to the process mechanism of maintaining the quality of a product's geographical indications. Having an effect on law enforcement based on the said legal protection is the supervision of the processing and marketing process of products that can provide 
solutions to the public to be able to distinguish which forms are geographical indication products and plant variety products. Therefore, the relevant parties must immediately conduct an inventory of the problem, both for the short and long term. Of course, the sponsor must be from a government that ideally has a high sensitivity to the problems that arise in the community. The government's efforts are oriented towards the maximum encouragement to the public to register geographical indications of local products to obtain legal protection in a manner that reflects orderly management. Not only as stated. At the practical level, institutions that have the authority must be able to carry out their duties in managing IP, especially helping the community to bring geographical indications, by the ideal of legal protection to the community. The above course is of course in a sustainable and structured manner through the socialization of legislation to the community, both ordinary citizens and government officials are very important. The aim is that the rules established are known, understood, and implemented by the community. Basically that many local community products are taken by outsiders and commercialized for profit, therefore local products need to be protected and have great control over geographical indication products so that they can improve the economy of the local communities that produce these geographical indication products to prevent the taking of carried out by outsiders as well as falsification of geographical indication products that affect the marketing level of a geographical indication product. This can be done product registration for the welfare of the community in the area because it has economic value that is not small. These legal safeguards are very important values for the continued development of products. Without adequate legal protection, not only gives a negative meaning to legal certainty but will eliminate the creativity and innovation of the community in making and developing new products. This is where the role of government as a form of responsibility in carrying out the mandate for the welfare of the people can be achieved. A very important and new sector is the development of local community products.

From the aspect of international trade law, the existence of the TRIPs policy is very beneficial to the economic interests of developing countries like Indonesia. Indonesia has a diversity of natural resources (resources) and biological resources (germplasm) scattered in various regions, which have been protected with the protection of geographical indications. The influence of the name of a variety of a product that has been protected by geographical indication is an obstacle in law enforcement and economic improvement of geographical indication products so that it is expected that both consumers and producers will not use the name of a similar variety with Geographical Indication products in the marketing system both locally and internationally. It is hoped that the community will be able to distinguish products as plant varieties and geographical indication products. Because many varieties of products are traded in the traditional market which for consumers are considered as similar products with geographical indication products. This can be known from the origin, characteristics, and quality of the product geographical indications. One variety of salak fruit (Salacca edulis) such as Salak Pondoh in the form of fresh fruit and its processed products has become a characteristic of Turi District, Sleman Regency, Special Region of Yogyakarta. Based on the information that in Japan, consumers only want to receive salak pondoh originating from Sleman, Yogyakarta. Whereas in Indonesia this type of salak pondoh variety is also widely planted in various regions under the name Salak pondoh. For consumers, especially in 
China, Singapore, or Japan, they certainly can distinguish between the "aroma" (Fragrance) and "taste" (flavor) that is typical of salak pondoh originating or grown in Sleman, when compared to other regions. With assistance from the Regional Government and after being formally requested by the Pondoh Salak Farmers Community of Sleman Regency, finally, this pondoh salak variety succeeded in obtaining a certificate of geographical indication in August 2013. This the geographical indication for the salak pondoh variety has become a "distinguishing sign" from salak pondoh varieties from other regions, even with salak varieties in general.

Geographical indications have positioned salak pondoh as a trade commodity whose quality is recognized so that it has added value to compete competitively. As long as the nature and characteristics of these products are maintained, they hope to contribute to the welfare of the community through various economic activities related to the salak commodity concerned.

Analysis of the discussion above that the implementation and application of law number 20 of 2016 concerning brands and geographical indications should provide a guarantee of protection regarding authenticity and quality that affect the characteristics and value of a product of geographical indications that are expected to be able to increase the economic value of the local communities producing regions. by taking into account the following matters:

3.2.1 Continual outreach to the people.

The community is expected to be able to distinguish the quality and value of geographical indication products from other superior products which are similar varieties. This continuous socialization must be further improved up to the consumer level.

3.2.2 Increased Control of the use of Products by related parties.

The government and the association of geographical indication product protection associations collaborate to supervise the application of the geographical indication product registration requirements book in the community to reduce the level of counterfeiting of products.

3.2.3 Use of labels by Geographical Indication Products.

Each geographical indication product that has received protection has labeling that has been approved in the implementation of product marketing as the consistency of product production and marketing. This labeling is expected to be used up to the marketing of geographical indication products even in the smallest products so that the public can know the original products of geographical indications.

3.2.4 Ongoing monitoring, evaluation, and coaching; legal protection.

The production of geographical indications is continuously maintained by the geographical indication protection requirements book.

3.2.5 Special facilitation for the development,

Processing and marketing of goods and/or Geographical Indication products by the local Government. The government is expected to provide special facilities in the marketing of geographical indication products in the sense that there is a separation between geographical indication products and other similar products in marketing. This familiarizes people with knowing more about the characteristics and quality of geographical indication products. 


\section{Conclusion}

Based on TRIPs Agreement Article 22 regarding geographical indications which states that: geographical indications are signs that identify an area of a member country, or region or region within that region as the origin of the goods, where the reputation, quality, and characteristics of the goods concerned are largely determined by factors geographical. Thus, the origin of a particular item attached to the reputation, characteristics, and quality of an item with a certain area is legally protected. Strengthening the law in the protection of geographical indications is greatly influenced by the system and implementation of legal protection in the supervision, management, and marketing of geographical indication products. Also, Geographical indication products in Indonesia are still dominated by agricultural products that have been registered as plant varieties. In the local marketing of the community as consumers, it is very difficult to distinguish between product varieties of plants and products of geographical indication, this affects the level of local demand for the results of geographical indication products.

Acknowledgements. The author thanks the Head of Semarang State University and Head of the Faculty of Law for providing facilities to join the International Conference at ICILS 2020 UNNES and the Educational Fund Management Institution as funders for the success of this international conference.

\section{References}

[1] Bigway Hutabarat, 2011, Protection Of Geographical Indication Of Indonesian Coffee Products, Submitted to Universitas International Airlangga

[2] Steven Van Uytsel, Geographical Indications in Japan A New Start, Kyushu University

[3] www.ijibssr.com

[4] Kartadjoemena, 1997, GATT-WTO and Uruguay Results, University of Indonesia Publisher, Jakarta

[5] Submitted to Universitas International Airlangga

[6] Saky Septiono, Protection of Indonesia Geographical Indications, 23 December 2011, in Kemal -Assegaf. Blogspot.com (accessed April 10, 2020)

[7] Submitted to Higher Education Commission Pakistan

[8] Media. Neliti.com

[9] Dewi Yustiarini, Biemo W. Soemardi. A Review of corruption in public procurement in Indonesia, IOP Conference Series: Materials Science and Engineering, 2020

[10] EU Law on Indications of Geographical Origin, 2014

[11] The Importance of Place: Geographical Indications as a Tool for local and Regional Development, Springer Science and Business Media LLC, 2017

[12] Submitted to Higher Education Commission Pakistan

[13] www. Scribd.com 
[14] Submitted to University of Sydney

[15] Steven Van Uytsel, Geographical Indications in Japan A New Start, Kyushu University

[16] Submitted to National Law School of India University, Bangalore

[17] Submitted to University of Edinburgh

[18] Submitted to Universitas Samratulangi

[19] Intellectual Property in Asia, Spinger Science and Businnes Media LLC, 2009

[20] Jurnal. Utu.ac.id

[21] Satjipto Rahardjo, Legal Studies, Citra Aditya Bakti, Bandung, 2000

[22] Satjipto Rahardjo, Legal Studies, Citra Aditya Bakti, Bandung, 2000 